\title{
Development and Comparison of Infiltration Models and their Field Validation
}

\author{
M. Rajasekhar ${ }^{1}$, D. Umabai ${ }^{2}$, K. Krupavathi ${ }^{3 *}$, I. Navyasai ${ }^{3}$ and R. Gopi ${ }^{4}$ \\ ${ }^{1}$ Indian Agricultural Research Institute, New Delhi, India \\ ${ }^{2}$ College of Agricultural Engineering, Bapatla, India \\ ${ }^{3}$ Rural Development Officer, Union Bank of India, Visakhapatnam, India \\ ${ }^{4}$ Micro Irrigation Engineer, Siflon Drip and Sprinklers, Ongole, India
}

*Corresponding author

\section{A B S T R A C T}

Infiltration is a dynamic process, variable in time and space and plays a vital role in the replenishment of soil water which is responsible for the growth and development of crops. Modelling of infiltration equation involves in finding out coefficients in the expressions

\section{Keywords}

Infiltration, Models, Infiltrometer, Validation

\section{Article Info}

Accepted:

20 September 2018

Available Online:

10 October 2018 for the curves infiltration rate and accumulated infiltration verses time and other parameters. The present study is aimed at determining the best fit infiltration model. Four equations including those of Kostiakov, Green Ampt, Horton's and Philip's were compared to determine which one most accurately predicted measured infiltration rates. For getting best fitting model for a particular soil and soil condition the results obtained from various infiltration models were compared with observed double ring infiltrometer data. Cultivation influences the infiltration rate by increasing the porosity of the surface soil and breaking up the surface seals is also considered in the present study. The experiment was done for cultivated and uncultivated bare soil conditions. The parameters considered for analysing the best fit model were coefficient of determination, correlation coefficient and standard error. The results shown that, the infiltration values obtained by Philip's model and Green-Ampt model are nearer to observed values. From the results it was finally concluded that the Philip's model with coefficient of determination 0.99 as well as correlation coefficient 0.99 and standard error 0.08 fits best to the observed values followed by Green-Ampt and Kostiakov.

\section{Introduction}

Infiltration is very important characteristic and plays an important role in design of farm irrigation, scheduling of irrigation, application rate of irrigation water, for calculation of conveyance losses, irrigation efficiency, field capacity, wilting point and field drainage, availability of nutrients, accumulation of salts, watershed modelling and prediction of surface runoff (Zerihun et al., 1996; Oyenarte et al., 2002 and Irmak et al., 2011). It is also used in planning water conservation techniques, and in land evaluation for liquids and effluent waste disposal (Mbagwu, 1993).

Infiltration is a dynamic process, variable in time and space. With the application of 
infiltration equation modelling of surface flow and understanding of these dynamic processes becomes an easier task. Modelling of infiltration equation involves in finding out coefficients in the expressions for the curves infiltration rate and accumulated infiltration verses time and other parameters. The infiltration models under examination in this paper are the Kostiakov, Green-Ampt, Hortons model and Philip Model. These models were chosen because they are based on empirical parameters. Empirical models are generally preferred over theoretical models because they reflect in-situ conditions (Wilson, 2017). The main objective of this study is to find the relationship between equations coefficients indifferent soils under different surface soil conditions.

\section{Materials and Methods}

The present experiment entitled "Development and comparison of infiltration models and their field validation" was conducted at the College of Agricultural Engineering, Madakasira. Madakasira was located in Anantapuram district of Andhrapradesh, The area has Latitude of $13^{\circ} 56^{\prime} 56.89^{\prime \prime} \mathrm{N}$ and longitude of $77^{\circ} 18^{\prime} 42^{\prime \prime} \mathrm{E}$. The Eye altitude of experiment location is 710 meters and elevation is 641.604 meters. The annual rainfall of Madakasira is $608.55 \mathrm{~mm}$. In Madakasira the predominant soils are silty loam soils. Materials used and methodology followed for the determination of the best fit model for the observation infiltration data was presented. The treatments planned in Cultivated cropped land $\left(\mathrm{T}_{1}\right)$ and Uncultivated cropped land $\left(\mathrm{T}_{2}\right)$

\section{Modeling of infiltration equations}

\section{Kostiakov equation}

Kostiakov (1932) and independently Lewis (1937) proposed a simple empirical infiltration equation based on curve fitting from field data. It relates infiltration to time as a power function:

$F_{p}=a t^{b}$

Where

$\mathrm{F}_{\mathrm{p}}=$ Cumulative infiltration capacity $[\mathrm{cm}]$, $\mathrm{t}=$ time after infiltration starts $[\mathrm{h}]$, and $\mathrm{a}$ and $\mathrm{b}$ [unit less] are constants that depend on the soil and initial conditions.

The parameters, $a$ and $b$ must be evaluated from measured infiltration data, since they have no physical interpretation. The equation describes the measured infiltration curve and given the same soil and same initial water condition, allows prediction of an infiltration curve using the same constants developed for those conditions.

Criddle et al., (1956) used the logarithmic form of the equation

$\log \mathrm{F}_{\mathrm{p}}=\log \mathrm{a}+\mathrm{b} \log \mathrm{t}$

To determine the parameter values for aand $b$ by plotting $\log \mathrm{Fp}$ against $\log t$, which results in a straight line if the Kostiakov equation is applicable to the data.

The intercept of the equation (infiltration rate at time $t=1)$ is $\log$ aand the slope is $b$.

\section{Green-Ampt equation}

Green and Ampt (GA) proposed in 1911 an approximate model that directly applies Darcy's law. The original equation was derived for infiltration from a ponded surface into a deep homogeneous soil with uniform initial water content. The GA model has been found to apply best to infiltration into uniform, initially dry, coarse textured soils which exhibit a sharply defined wetting front. 
$\mathrm{I}=\mathrm{m}+\mathrm{n} / \mathrm{F}$

Where

I is infiltration capacity $(\mathrm{cm} / \mathrm{h})$,

$F$ is cumulative infiltration $(\mathrm{cm})$,

$\mathrm{m}$ and $\mathrm{n}$ are Green - Ampt parameters of infiltration.

\section{Horton's equation}

Horton recognized that infiltration capacity (I) decreased with time until it approached a minimum constant rate $\left(f_{c}\right)$ (Horton, 1939).

He attributed this decrease in infiltration primarily to factors operating at the soil surface rather than to flow processes within the soil discovered. Horton's perceptual model of infiltration processes was far more sophisticated and complete than normally presented in hydrological texts.

$I=f_{c}+\left(f_{o}-f_{c}\right) e^{-k t}$

Where

$\mathrm{I}=$ the infiltration capacity or potential infiltration rate $[\mathrm{cm} / \mathrm{h}]$,

$\mathrm{f}_{\mathrm{c}}=$ the final constant infiltration rate $[\mathrm{cm} / \mathrm{h}]$,

$\mathrm{f}_{\mathrm{o}}=$ the infiltration capacity at $\mathrm{t}=0[\mathrm{~cm} / \mathrm{h}]$,

$\mathrm{k}=$ Horton's decay coefficient which depends upon soil characteristics and vegetation cover

$\mathrm{t}=$ time after start of infiltration $(\mathrm{h})$.

The parameters, $\mathrm{f}_{\mathrm{o}}, \mathrm{k}$, and $\mathrm{f}_{\mathrm{c}}$ must be evaluated from measured infiltration data. Subtracting $f_{c}$ from both sides of equation and then taking the natural log of each side gives the following equation for a straight line.

$\ln (\mathrm{I}-\mathrm{fc})=\ln (\mathrm{fo}-\mathrm{fc})-\mathrm{kt}$

\section{Phillip's equation}

Philip (1957) proposed that by truncating his series solution for infiltration from a ponded surface after the first two terms, a concise infiltration rate equation could be obtained which would be useful for small times. The resulting equation is,

$I=\frac{s}{2} t^{-1 / 2}+K$

Where

$\mathrm{I}=$ infiltration rate $[\mathrm{cm} / \mathrm{h}]$

$\mathrm{S}=\mathrm{a}$ function of soil suction potential and called as sorptivity.

$\mathrm{t}=$ time after start of infiltration $[\mathrm{h}]$

$\mathrm{K}=$ rate constant.

The above models were validated with observed values taken from the experiments done in two treatment plots i.e Cultivated cropped land and Uncultivated cropped land using double ring infiltrometer setup. To verify the data statistically, three parameters namely coefficient of determination, Correlation coefficient and standard error was selected.

The coefficient of determination shows the accurate model which is suitable for a particular soil is determined. As the coefficient of determination closer to one value express the best fitting equation. Estimating the correlation coefficient is useful to determine the relationship between observed data and calculated data of infiltration rate.

The mathematical formula for computing $r$ is:

$\mathrm{r}=\frac{\mathrm{n} \sum \mathrm{xy}-\left(\sum \mathrm{x}\right)\left(\sum \mathrm{y}\right)}{\sqrt{\mathrm{n}\left(\sum \mathrm{x}^{2}\right)-\left(\sum \mathrm{x}\right)^{2}} \sqrt{\mathrm{n}\left(\mathrm{y}^{2}\right)-\left(\sum \mathrm{y}\right)^{2}}}$ 
Where, $n$ is the number of pairs of data

As the standard error closer to zero value is considered to be the best fitted model.

The standard error was calculated using the given formula.

Standard Error $=\frac{\sigma}{\sqrt{n}}$

Where,

$\sigma=$ Standard deviation

$\mathrm{n}=$ no of observations

\section{Results and Discussion}

To develop best fit infiltration model for the soils, the selected four popular best fit equation models are and their constants of the models are found out as follows.

\section{Kostiakov equation}

The constants from kostiakov equation $a$ and $b$ are found out by drawing a graph between $\ln (\mathrm{Fp})$ against $\ln (\mathrm{t})$. Relationships (Fig. 1 and 2) between parameters $\ln (\mathrm{Fp})$ and $\operatorname{Ln}(\mathrm{t})$ for treatments $T_{1}$ and $T_{2}$ have been arrived on the basis of dimensional analysis and are plotted from data presented in Table 1.

Based on the constants from the analysis, infiltration rate, I has been calculated, for reference it was presented in Table 1 for treatment $\mathrm{T}_{1}$.

Developed Kostiakov equations for different treatments are as follows

Cultivated cropped land $\left(\mathrm{T}_{1}\right) \mathrm{Fp}=4.850103 \times$ $\mathrm{t}^{0.529}$

Uncultivated cropped land $\left(\mathrm{T}_{2}\right) \mathrm{Fp}=1.91363 \times$ $\mathrm{t}^{0.446}$

\section{Green-Ampt Equation}

The constants from the Green-Ampt equation $\mathrm{m}$ and $\mathrm{n}$ are found out by drawing a graph between I against 1/Fp. Relationships (Fig. 3 and 4) between parameters I and $1 / \mathrm{Fp}$ for treatments $T_{1}$ and $T_{2}$ have been arrived on the basis of dimensional analysis.

Based on the constants from the analysis, infiltration rate, I has been calculated.

Developed Green-Ampt equations for different treatments are as follows

Cultivated cropped land $\left(\mathrm{T}_{1}\right) \mathrm{I}=-0.468+$ 15.48

Fp

Uncultivated cropped land $\left(\mathrm{T}_{2}\right) \mathrm{I}=-0.331+$ Fp

\section{Horton's equation}

The constants from Horton's equation k decay coefficient is found out by drawing a graph between $\ln (\mathrm{I}-\mathrm{fc})$ against time, t. Relationships (Fig. 5 and 6) between parameters $\ln (\mathrm{I}-\mathrm{fc}$ ) and time, $t$ for treatments $T_{1}$ and $T_{2}$ have been arrived on the basis of dimensional analysis. Based on the constants from the analysis, infiltration rate, I has been calculated.

Developed Horton's equations for different treatments are as follows

Cultivated cropped land $\left(\mathrm{T}_{1}\right) \mathrm{I}=0.3+6.9639$ $x \mathrm{e}^{-0.733 \mathrm{t}}$

Uncultivated cropped land $\left(\mathrm{T}_{2}\right) \mathrm{I}=0.16+5 \times \mathrm{e}^{-}$ $1.461 \mathrm{t}$

The constants from the Philip's equation K and $S$ are found out by drawing a graph between $\mathrm{K}$ against $\mathrm{S}$. 
Fig.1 Relationship between $\ln (\mathrm{Fp})$ and $\ln (\mathrm{t})$ of cultivated cropped land $\left(\mathrm{T}_{1}\right)$ for Kostiakov model

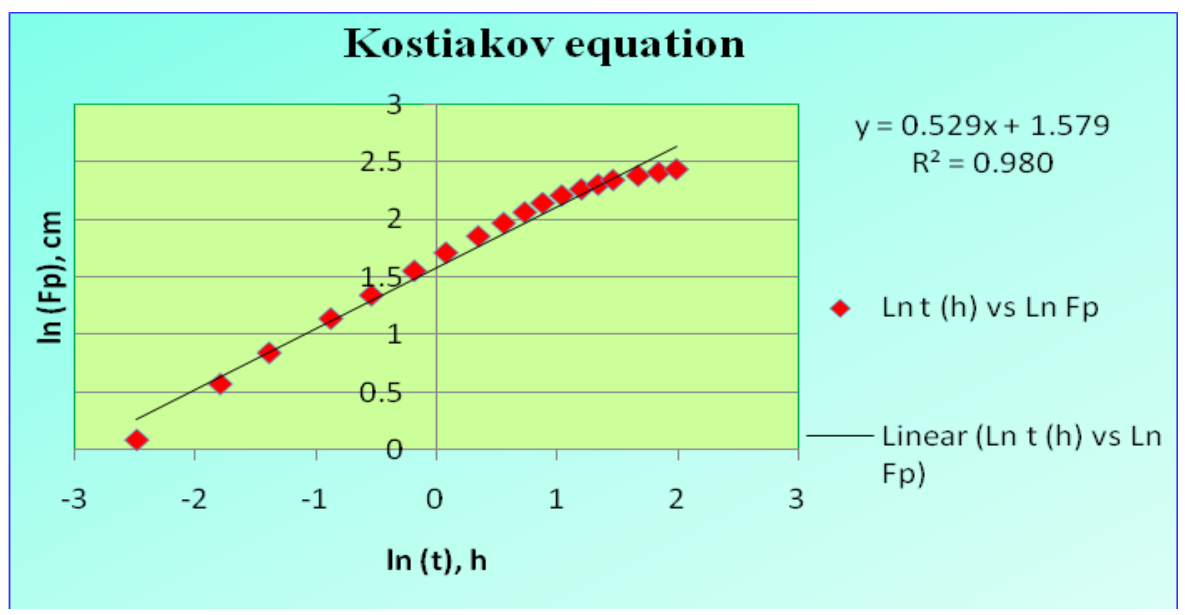

Fig.2 Relationship between $\ln (\mathrm{Fp})$ and $\ln (\mathrm{t})$ of uncultivated cropped land $\left(\mathrm{T}_{2}\right)$ for Kostiakov model

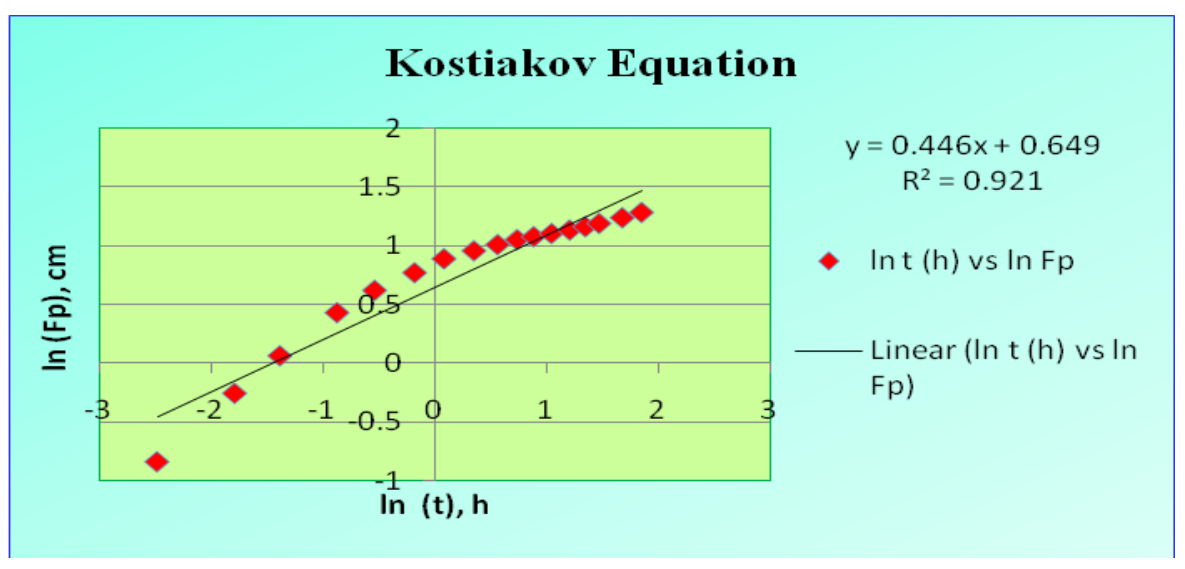

Fig.3 Relationship between I, cm/h and 1/Fp of cultivated cropped land $\left(\mathrm{T}_{1}\right)$ for green Ampt model

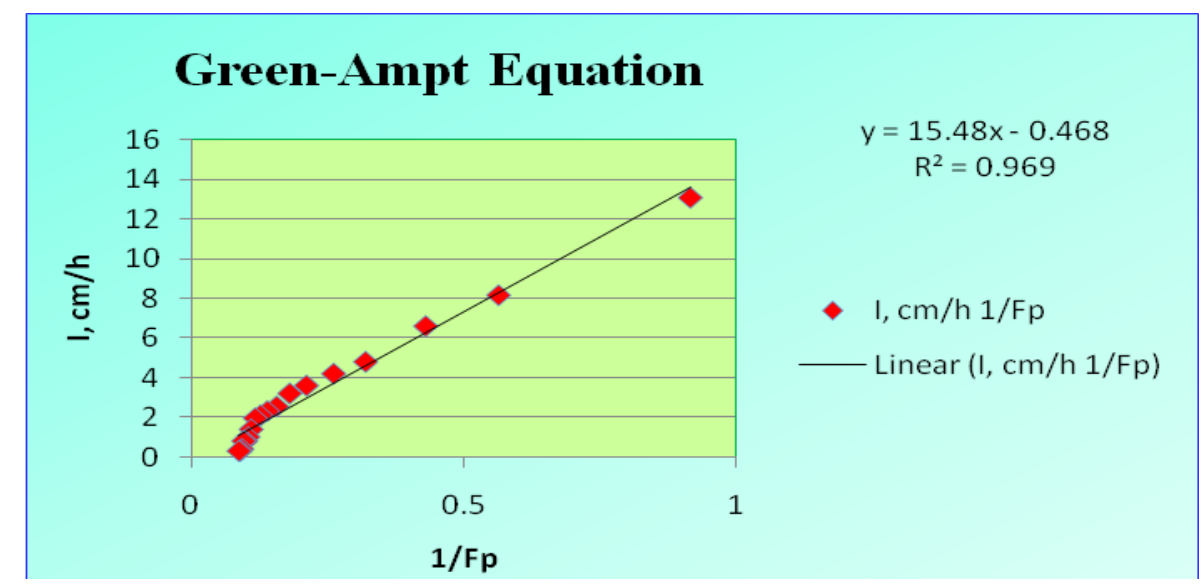


Fig.4 Relationship between I, cm/h and 1/Fp of uncultivated cropped land (T2) for green Ampt model

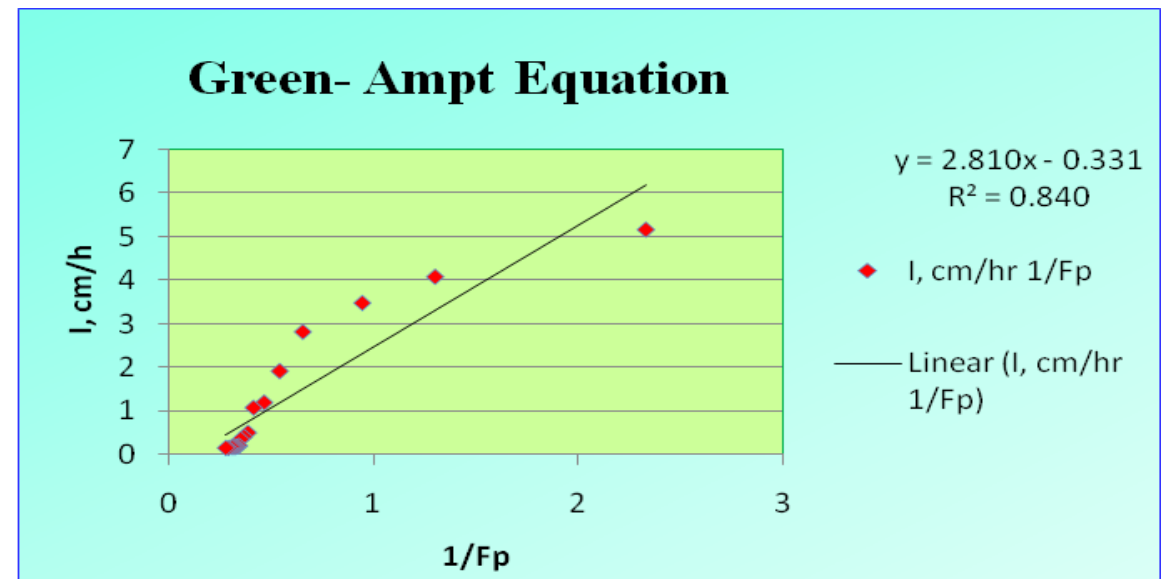

Fig.5 Relationship between $\operatorname{Ln}(\mathrm{fp}-\mathrm{fc})$ and Time $(\mathrm{h})$ of cultivated cropped land $\left(\mathrm{T}_{1}\right)$ for Horton's model

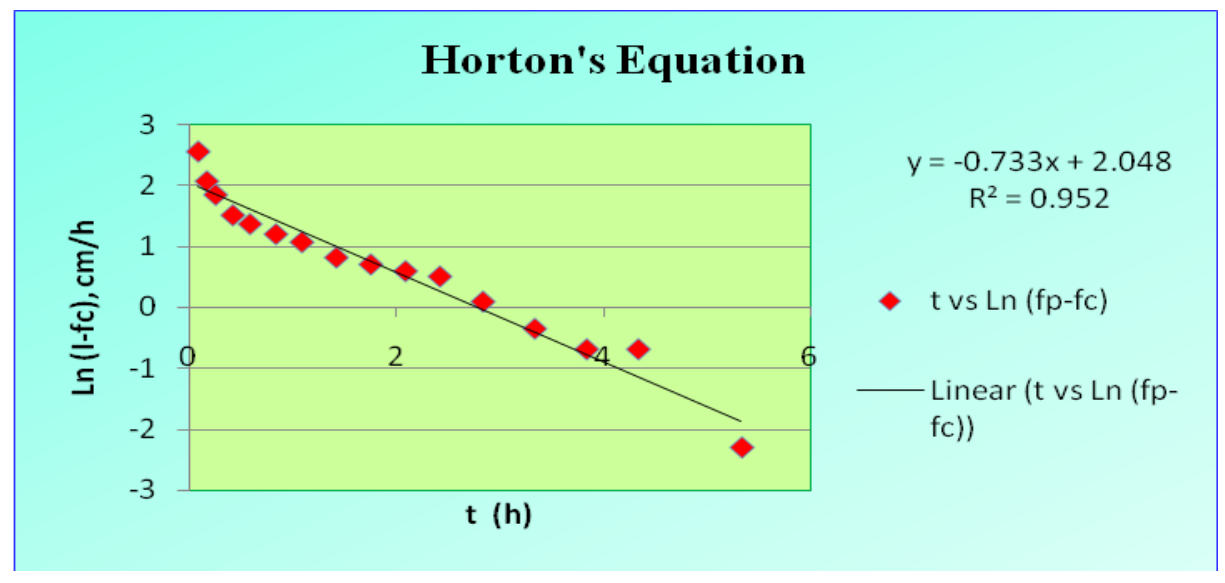

Fig.6 Relationship Between Ln(fp-fc) and Time(h) of uncultivated cropped land $\left(\mathrm{T}_{2}\right)$ for Horton's model

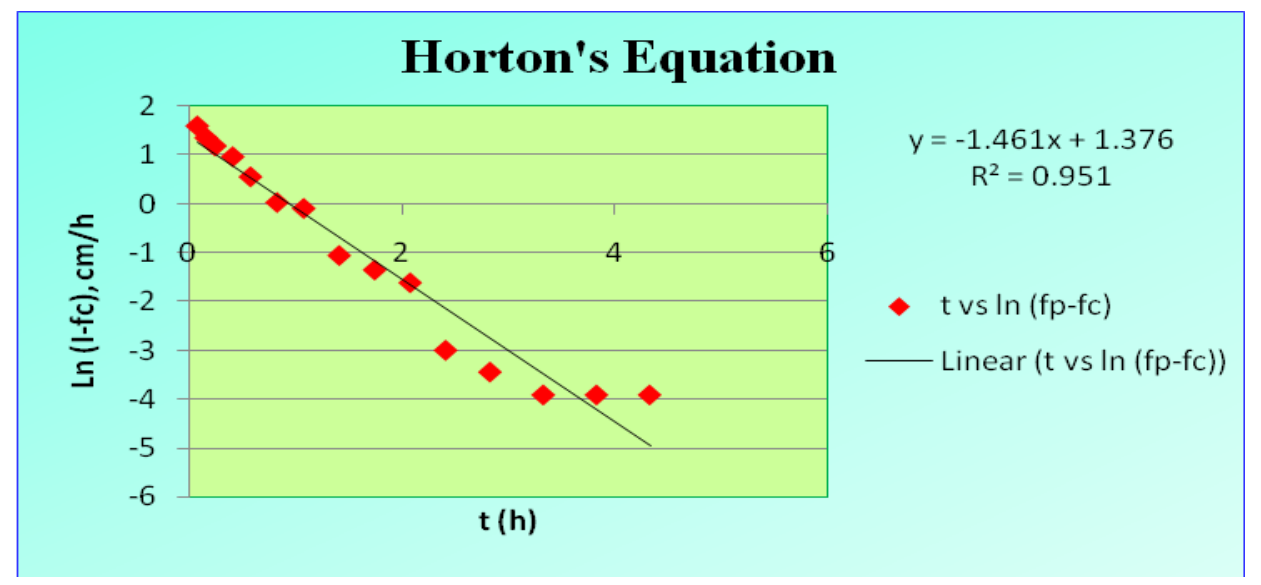


Fig.7 Relationship between $\mathrm{I}, \mathrm{cm} / \mathrm{h}$ and power $(\mathrm{t},-0.5)$ of cultivated cropped land $\left(\mathrm{T}_{1}\right)$ for Philip's model

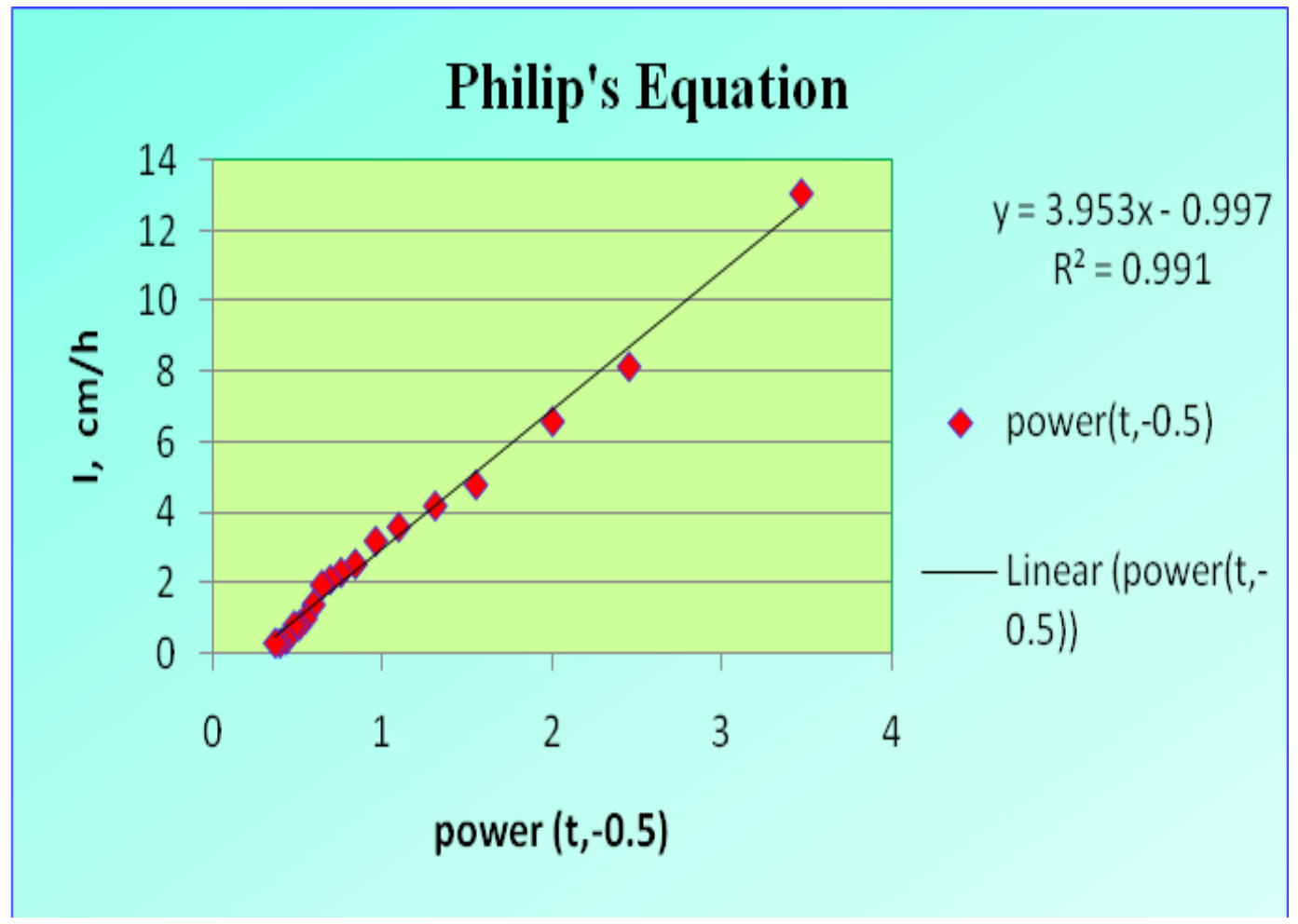

Fig.8 Relationship between $\mathrm{I}, \mathrm{cm} / \mathrm{h})$ and power $(\mathrm{t},-0.5)$ of uncultivated cropped land $\left(\mathrm{T}_{2}\right)$ for Philip's model

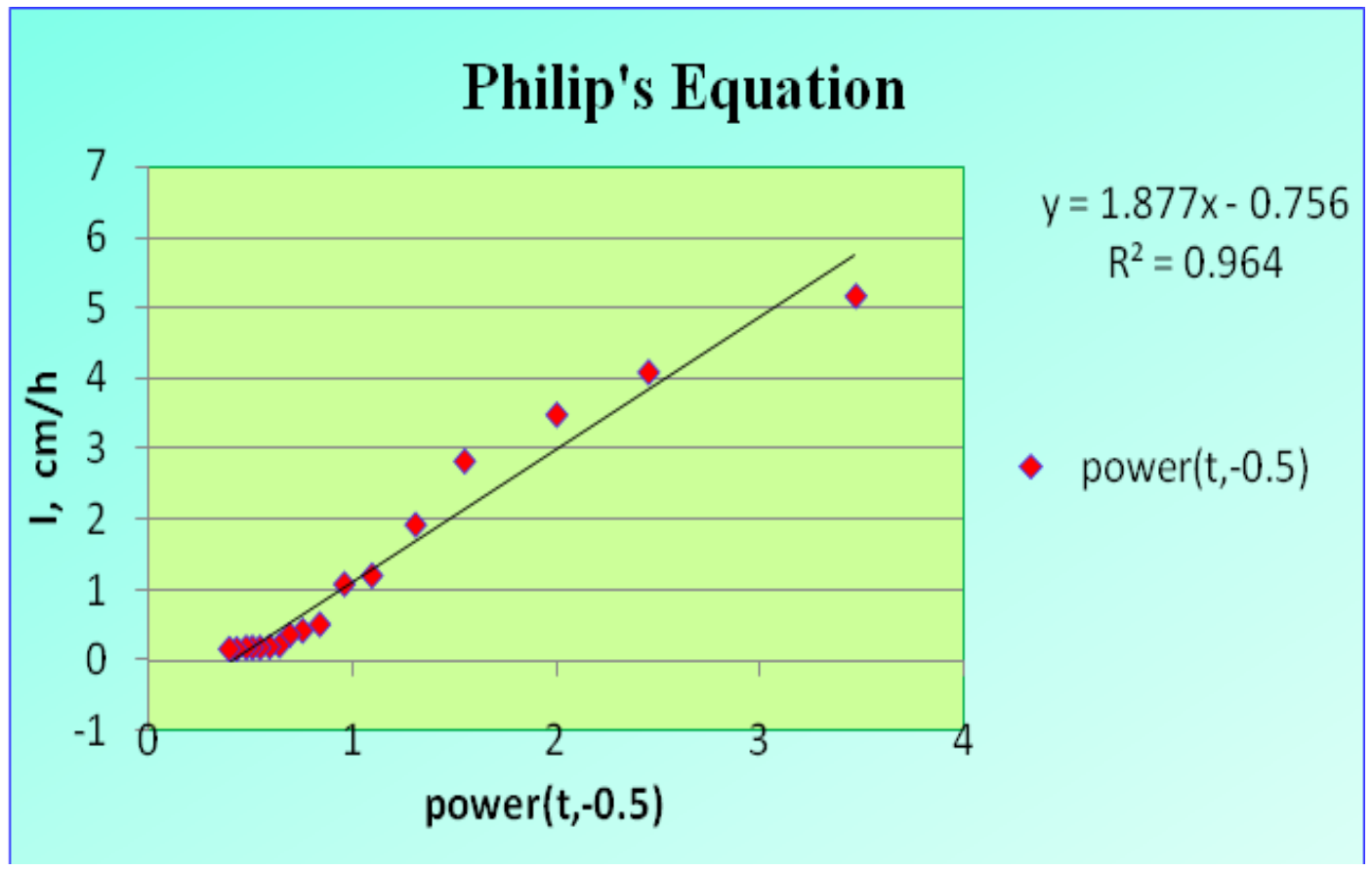


Table.1 Observed infiltration rates and calculations of cultivated cropped land $\left(T_{1}\right)$ for Kostiakov model

\begin{tabular}{|c|c|c|c|c|c|c|}
\hline $\begin{array}{l}\text { Time, } \\
\text { min }\end{array}$ & Time, h & Fp,cm & $\ln (t), \mathbf{h}$ & $\begin{array}{c}\text { ln (Fp) } \\
\text { cm }\end{array}$ & $\begin{array}{c}\text { calcFp, } \\
\text { cm }\end{array}$ & $\begin{array}{l}\text { cal I, } \\
\mathrm{cm} / \mathrm{h}\end{array}$ \\
\hline 5 & .083333 & 1.09 & 91 & 0.086178 & 1.302759 & .209914 \\
\hline 10 & 0.166667 & 1.77 & -1.79176 & 0.57098 & 1.879788 & 5.966448 \\
\hline 15 & 0.25 & 2.32 & -1.38629 & 0.841567 & 2.329492 & 4.929205 \\
\hline 25 & 0.416667 & 3.12 & -0.87547 & 1.137833 & 3.052244 & 3.875129 \\
\hline 35 & 0.583333 & 3.82 & -0.539 & 1.34025 & 3.646876 & 7195 \\
\hline 50 & 0.833333 & 4.72 & -0.18232 & 1.551809 & 4.40417 & 5767 \\
\hline 65 & 1.083333 & 5.52 & 0.080043 & 1.708378 & 5.059879 & 778 \\
\hline 85 & 1.416667 & 6.37 & 0.348307 & 1.851599 & 5.831383 & 2.177507 \\
\hline 105 & 1.75 & 7.14 & 0.559616 & 1.965713 & 6.521058 & 1.971223 \\
\hline 125 & 2.083333 & 7.84 & 0.733969 & 2.059239 & 7.151125 & 1.815814 \\
\hline 145 & 2.416667 & 8.49 & 0.882389 & 2.138889 & 7.735219 & 1.693213 \\
\hline 170 & 2.833 & 9.07 & 1.04 & 2.2 & & 1.570994 \\
\hline 200 & 3.333333 & 9.57 & 1.203973 & 2.258633 & 9.169672 & 1.455227 \\
\hline 230 & 3.833333 & 9.97 & 1.343735 & 2.299581 & 9.873315 & 1.362517 \\
\hline 260 & 4.333333 & 10.37 & 1.466337 & 2.338917 & 10.53489 & 1.286067 \\
\hline 320 & 5.333333 & 10.77 & 1.673976 & 2.376764 & 11.758 & 1.166246 \\
\hline 380 & 6.333333 & 11.07 & 1.845827 & 2.404239 & 12.87699 & 1.075568 \\
\hline 440 & 7.333333 & 11.37 & 1.99243 & 2.430978 & 13.91539 & 1.003806 \\
\hline
\end{tabular}

Table.2 The values of different parameters of infiltration models for two soil conditions

\begin{tabular}{|c|c|c|c|c|c|c|}
\hline \multirow[t]{2}{*}{ Soil type } & \multicolumn{2}{|c|}{ Kostiakov } & \multicolumn{2}{|c|}{ Green Ampt } & \multirow{2}{*}{$\begin{array}{l}\text { Horton's } \\
\text { k }\end{array}$} & \multirow{2}{*}{$\begin{array}{c}\text { Philip's } \\
\text { K }\end{array}$} \\
\hline & $\mathbf{a}$ & b & m & $\mathbf{n}$ & & \\
\hline $\begin{array}{c}\text { Cultivated } \\
\text { cropped } \\
\text { land }\left(\mathrm{T}_{1}\right)\end{array}$ & 4.8501 & 0.529 & -0.468 & 15.48 & -0.733 & -0.997 \\
\hline $\begin{array}{l}\text { Uncultivate } \\
\text { d cropped } \\
\text { land }\left(\mathrm{T}_{2}\right)\end{array}$ & $\begin{array}{c}1.9136 \\
3\end{array}$ & 0.446 & -0.331 & 2.81 & -1.461 & -0.756 \\
\hline
\end{tabular}


Table.3 Comparison between observed and calculated infiltration rates by different infiltration models for cultivated cropped land and uncultivated cropped land

\begin{tabular}{|c|c|c|c|c|c|c|c|c|c|c|}
\hline \multirow[t]{2}{*}{$\begin{array}{c}\text { Time, } \\
\text { h }\end{array}$} & \multicolumn{2}{|c|}{$\begin{array}{l}\text { Observed Infiltration } \\
\text { rate, } \mathrm{cm} / \mathrm{h}\end{array}$} & \multicolumn{2}{|c|}{$\begin{array}{c}\text { Infiltration rate by } \\
\text { Kostiakov model, cm/h }\end{array}$} & \multicolumn{2}{|c|}{$\begin{array}{c}\text { Infiltration rate by } \\
\text { Green Ampt model, } \mathrm{cm} / \mathrm{h}\end{array}$} & \multicolumn{2}{|c|}{$\begin{array}{l}\text { Infiltration rate by } \\
\text { Horton's model, } \mathrm{cm} / \mathrm{h}\end{array}$} & \multicolumn{2}{|c|}{$\begin{array}{l}\text { Infiltration rate by } \\
\text { Philip's model, } \mathrm{cm} / \mathrm{h}\end{array}$} \\
\hline & $\begin{array}{c}\text { Cultivated } \\
\text { cropped } \\
\text { land (T1) }\end{array}$ & $\begin{array}{c}\text { Uncultivated } \\
\text { cropped } \\
\text { land (T2) }\end{array}$ & $\begin{array}{c}\text { Cultivated } \\
\text { cropped } \\
\text { land (T1) }\end{array}$ & $\begin{array}{c}\text { Uncultivated } \\
\text { cropped } \\
\text { land (T2) }\end{array}$ & $\begin{array}{c}\text { Cultivated } \\
\text { cropped } \\
\text { land (T1) }\end{array}$ & $\begin{array}{l}\text { Uncultivated } \\
\text { cropped } \\
\text { land (T2) }\end{array}$ & $\begin{array}{c}\text { Cultivated } \\
\text { cropped } \\
\text { land (T1) }\end{array}$ & $\begin{array}{l}\text { Uncultivated } \\
\text { cropped } \\
\text { land (T2) }\end{array}$ & $\begin{array}{c}\text { Cultivated } \\
\text { cropped } \\
\text { land (T1) }\end{array}$ & $\begin{array}{l}\text { Uncultivated } \\
\text { cropped } \\
\text { land (T2) }\end{array}$ \\
\hline 0.00 & 0 & 0 & 0 & 0 & 0 & 0 & 0 & 0 & 0 & 0 \\
\hline 0.08 & 13.08 & 5.16 & 8.27 & 3.38 & 13.73 & 6.20 & 6.85 & 4.59 & 12.70 & 5.75 \\
\hline 0.17 & 8.16 & 4.08 & 5.97 & 2.30 & 8.28 & 3.32 & 6.46 & 4.08 & 8.69 & 3.84 \\
\hline 0.25 & 6.6 & 3.48 & 4.93 & 1.84 & 6.20 & 2.32 & 6.10 & 3.63 & 6.91 & 3.00 \\
\hline 0.42 & 4.8 & 2.82 & 3.88 & 1.39 & 4.49 & 1.51 & 5.43 & 2.88 & 5.13 & 2.15 \\
\hline 0.58 & 4.2 & 1.92 & 3.31 & 1.15 & 3.58 & 1.19 & 4.84 & 2.29 & 4.18 & 1.70 \\
\hline 0.83 & 3.6 & 1.2 & 2.80 & 0.94 & 2.81 & 0.98 & 4.08 & 1.64 & 3.33 & 1.30 \\
\hline 1.08 & 3.2 & 1.08 & 2.47 & 0.82 & 2.34 & 0.83 & 3.45 & 1.19 & 2.80 & 1.05 \\
\hline 1.42 & 2.55 & 0.51 & 2.18 & 0.70 & 1.96 & 0.75 & 2.77 & 0.79 & 2.32 & 0.82 \\
\hline 1.75 & 2.31 & 0.42 & 1.97 & 0.63 & 1.70 & 0.70 & 2.23 & 0.55 & 1.99 & 0.66 \\
\hline 2.08 & 2.1 & 0.36 & 1.82 & 0.57 & 1.51 & 0.65 & 1.81 & 0.40 & 1.74 & 0.54 \\
\hline 2.42 & 1.95 & 0.21 & 1.69 & 0.52 & 1.36 & 0.63 & 1.48 & 0.31 & 1.55 & 0.45 \\
\hline 2.83 & 1.392 & 0.192 & 1.57 & 0.48 & 1.24 & 0.61 & 1.17 & 0.24 & 1.35 & 0.36 \\
\hline 3.33 & 1 & 0.18 & 1.46 & 0.44 & 1.15 & 0.58 & 0.90 & 0.20 & 1.17 & 0.27 \\
\hline 3.83 & 0.8 & 0.18 & 1.36 & 0.41 & 1.08 & 0.55 & 0.72 & 0.18 & 1.02 & 0.20 \\
\hline 4.33 & 0.8 & 0.18 & 1.29 & 0.38 & 1.02 & 0.53 & 0.59 & 0.17 & 0.90 & 0.15 \\
\hline 0.00 & 0.4 & 0 & 1.17 & & 0.97 & & 0.44 & & 0.71 & \\
\hline 0.08 & 0.3 & 5.16 & 1.08 & & 0.93 & & 0.37 & & 0.57 & \\
\hline 0.17 & 0 & 4.08 & 0 & & 0 & & 0 & & 0 & \\
\hline \multicolumn{3}{|c|}{ Coefficient of Determination } & 0.98 & 0.92 & 0.97 & 0.84 & 0.95 & 0.95 & 0.99 & 0.96 \\
\hline \multicolumn{3}{|c|}{ Correlation Coefficient } & 0.98 & 0.94 & 0.97 & 0.92 & 0.91 & 0.97 & 0.99 & 0.98 \\
\hline \multicolumn{3}{|c|}{ Standard Error } & 0.48 & 0.22 & 0.183 & 0.40 & 0.55 & 0.40 & 0.08 & 0.241 \\
\hline
\end{tabular}


Relationships (Fig. 7 and 8) between parameters $K$ and $S$ for treatments $T_{1}$ and $T_{2}$ have been arrived on the basis of dimensional analysis. Based on the constants from the analysis, infiltration rate, I has been calculated.

Developed Philip's equations for different treatments are as follows

Cultivated cropped land $\left(\mathrm{T}_{1}\right) \mathrm{I}=3.953 \times \mathrm{t}^{-0.5}$ 0.977

Uncultivated cropped land $\left(\mathrm{T}_{2}\right) \mathrm{I}=1.877 \times \mathrm{t}^{-0.5}$ $-0.756$

The values of different parameters of infiltration models for different soil conditions, i.e. Cultivated cropped land, Uncultivated cropped land, and Grassed land were shown in table 2 .

\section{Comparison of observed and predicted infiltrations}

The computed values of infiltration rates by different models for cultivated cropped land and uncultivated cropped land was presented in table 3. Initial infiltration rate predicted by Philip's equation is $12.70 \mathrm{~cm} / \mathrm{h}$, which is near to observed infiltration rate $13.08 \mathrm{~cm} / \mathrm{h}$. The same value predicted by Horton's equation is 6.85 differentiating highly from observed value. The infiltration rates decreased from 8.27 to $1.08 \mathrm{~cm} / \mathrm{h}$ for Kostiakov, 13.73 to 0.93 for Green-Ampt, 6.85 to $0.37 \mathrm{~cm} / \mathrm{h}$ for Horton's and 12.70 to $0.57 \mathrm{~cm} / \mathrm{h}$ for Philip's model respectively. From the results is clear that the infiltration values obtained by Philip's model and Green-Ampt model are nearer to observed values. The Coefficient of determination for different models were 0.98 , 0.97, 0.95 and 0.99 as well as Correlation coefficients are $0.98,0.97,0.91$ and 0.99 for Kostiakov, Green-Ampt, Horton's and Philip's model respectively. The standard errors for different models were $0.48,0.183$, 0.55, 0.08 for Kostiakov, Green-Ampt, Horton's and Philip's model respectively.

In case of uncultivated land, the initial infiltration rate predicted by Horton's equation is $4.59 \mathrm{~cm} / \mathrm{h}$, which is near to observed infiltration rate $5.16 \mathrm{~cm} / \mathrm{h}$. The same value predicted by Kostiakov equation is 3.38 differentiating highly from observed value. The infiltration rates decreased from 3.38 to $0.38 \mathrm{~cm} / \mathrm{h}$ for Kostiakov, 6.20 to 0.53 for Green-Ampt, 4.59 to $0.17 \mathrm{~cm} / \mathrm{h}$ for Horton's and 5.75 to $0.15 \mathrm{~cm} / \mathrm{h}$ for Philip's model respectively. The Coefficient of determination for different models were 0.92, 0.84, 0.95 and 0.96 as well as Correlation coefficients are $0.94,0.92,0.97$ and 0.98 for Kostiakov, Green-Ampt, Horton's and Philip's model respectively. The standard errors for different models were $0.22,0.40,0.40,0.241$ for Kostiakov, Green-Ampt, Horton's and Philip's model respectively. From the results it was finally concluded that both treatments the Philip's model fitted best to the observed values followed by Green-Ampt and Kostiakov in case of cultivated land and Horton's model in case of uncultivated land.

Coefficients in the expressions for the curves infiltration rate and accumulated infiltration verses time and other parameters were developed for modelling of infiltration equation. The best fit infiltration models were determined by characterizing the data using coefficient of determination, correlation coefficient and standard error for the predicted and observed values. Four equations including those of Kostiakov, Green Ampt, Horton's and Philip's were compared to determine which one most accurately predicted measured infiltration rates. In the cultivated cropped land the Philip's model with coefficient of determination 0.99 as well as correlation coefficient 0.99 and standard error 0.08 fits best to the observed values 
followed by Green-Ampt and Kostiakov. In uncultivated cropped land, the Philip's model with Coefficient of determination 0.96 as well as Correlation coefficient 0.98 and standard error 0.241 fits best to the observed values followed by Horton's and kostiakov. The basic infiltration rate for cultivated cropped land and uncultivated cropped land was 0.3, and $0.16 \mathrm{~cm} / \mathrm{h}$ respectively

\section{References}

Criddle, W. D. 1956. Method for evaluating irrigation systems. Agriculture Handbook, 82, 2-11.

Horton, R.E., 1939. Analysis of runoff- plat experiments with varying infiltration- capacity. Eos, Transactions American Geophysical Union, 20(4), pp.693-711.

Irmak, S., Odhiambo, L. O., Kranz, W. L., \& Eisenhauer, D. E. 2011. Irrigation efficiency and uniformity, and crop water use efficiency. Biological Systems Engineering: Papers and Publications. 451.

Kostiakov, A. N. 1932. On the dynamics of coefficient of water percolation in soils and on the necessity of studying it from a dynamic point of view for purposes of amelioration. Trans. Sixth Comm. Intl. Soc. Soil Sci. Part A, 17-21.

Lewis, M. R. 1937. The rate of infiltration of water in irrigation- practice. Eos, Transactions American Geophysical Union, 18(2), 361-368.

Mbagwu JSC. 1993. Analysis of physical properties controlling steady-state infiltrationrates on tropical savannah soils. Internal Report No. IC/93/289.

Oyenarte, N.A, Mateos L, Palomo, M.J.2002. Infiltration variability in furrow irrigation. J. Irrig. Drain. Eng. ASCE128: 26-33.

Philip, J. R. (1957). The theory of infiltration: 4. Sorptivity and algebraic infiltration equations. Soil science, 84(3), 257-264.

Wilson, R.L. 2017. Comparing Infiltration Models to Estimate Infiltration Potential at Henry V Events.

Zerihun, D., J. Feyen, Reddy, J.M. 1996. Sensitivity analysis of furrow-irrigation performance parameters J. Irrig. Drain. Eng. ASCE 122: 49-57.

\section{How to cite this article:}

Rajasekhar, M., D. Umabai, K. Krupavathi, I. Navyasai and Gopi, R. 2018. Development and Comparison of Infiltration Models and Their Field Validation. Int.J.Curr.Microbiol.App.Sci. 7(10): 2691-2701. doi: https://doi.org/10.20546/ijcmas.2018.710.313 